\title{
OPTIMASI PENEMPATAN TITIK INTERKONEKSI DISTRIBUTED GENERATION (DG) PLTM MUARA PADA PENYULANG PANJI DENGAN METODE GENETIC ALGORITHM (GA)
}

\author{
I Komang Wahyu Trisna Putra ${ }^{1}$, Ngakan Putu Satriya Utama ${ }^{2}$, I Nyoman Setiawan ${ }^{3}$ \\ Program Studi Teknik Elektro, Fakultas Teknik, Universitas Udayana \\ Email: komangwahyutrisnaputra@gmail.com ${ }^{1}$, ngakansatriya@ee.unud.ac.id², \\ setiawan@unud.ac.id ${ }^{3}$
}

\begin{abstract}
Abstrak
Salah satu Distributed Generation (DG) yang beroperasi di Bali adalah Pembangkit Listrik Tenaga Minihidro (PLTM) yang yang berada di Desa Sambangan, Kabupaten Buleleng. PLTM tersebut terhubung dengan salah satu penyulang di daerah Buleleng yaitu Penyulang Panji. PLTM tersebut memiliki kapasitas pembangkit sebesar 2 × 1,15 MW yang mampu membantu suplai daya listrik ke Penyulang Panji selain pasokan daya listrik dari Gardu Induk Pemaron. PLTM mampu memberikan pengaruh penurunan rugi daya (losses), namun penempatan titik interkoneksi yang kurang tepat dapat menyebabkan penurunan rugi-rugi daya yang kurang maksimal. Pada Penelitian ini dilakukan optimasi penempatan titik interkoneksi PLTM dengan metode Genetic Algorithm (GA) dan didapatkan lokasi terbaik titik interkoneksi PLTM berada pada bus 70 dengan rugi-rugi daya total sebesar $31 \mathrm{~kW}$. Interkoneksi PLTM pada bus tersebut dapat menurunkan rugi-rugi daya aktif sebesar 5 kW dari total rugi-rugi daya awal saat kondisi eksisting yaitu pada bus 35 sebesar $36 \mathrm{~kW}$ menjadi $31 \mathrm{~kW}$.
\end{abstract}

\section{Kata kunci :Distributed Generation, Rugi-Rugi Daya, Genetic Algorithm}

\section{PENDAHULUAN}

Pemanfaatan pembangkit listrik energi fosil secara terus menerus merupakan faktor utama berkurangnya sumber energi yang tersedia. Diperlukan pengembangan suatu sistem tenaga listrik yang memprioritaskan pemakaian energi terbarukan (renewable energy) karena lebih ramah lingkungan, berkelanjutan, dan lebih ekonomis yaitu Distributed Generation (DG) yang biasanya terletak dekat dengan beban pada sistem distribusi tenaga listrik [1]. Pemenuhan kebutuhan energi listrik ini dilakukan dengan memanfaatkan potensi alam/sumber energi terbarukan seperti angin, air, matahari, panas bumi, gelombang laut, dan biomassa untuk menghasilkan energi listrik.

Salah satu DG yang beroperasi di Bali adalah Pembangkit Listrik Tenaga Minihidro (PLTM) yang berada di Desa Sambangan, Kabupaten Buleleng. Pembangkit terdistribusi tersebut terhubung dengan salah satu penyulang di daerah Buleleng yaitu Penyulang Panji. PLTM yang terhubung dengan Penyulang Panji memiliki kapasitas pembangkit sebesar $2 \times 1,15 \mathrm{MW}$ yang diharapkan dapat membantu suplai daya listrik ke Penyulang Panji selain pasokan daya listrik dari Gardu Induk Pemaron. Kondisi eksisting dari PLTM interkoneksi pada bus 35 yaitu pada bus trafo SK64. Dari titik interkoneksi tersebut pada Penyulang Panji terdapat rugirugi daya total sebesar $36 \mathrm{~kW}$. Interkoneksi PLTM pada bus sistem distribusi memberikan pengaruh penurunan rugi daya listrik, namun penempatan titik interkoneksi yang kurang tepat dapat menyebabkan penurunan rugi daya listrik yang kurang maksimal.

Salah satu hal yang penting dibahas pada DG adalah mengenai optimasi titik interkoneksinya. Optimasi ini bertujuan untuk mendapatkan nilai rugi daya seminimal mungkin dibanding dengan rugi daya pada kondisi eksisting. 
Dalam kasus optimasi penempatan titik interkoneksi DG sudah dilakukan dengan banyak metode. Masing-masing metode mempunyai kelemahan dan kelebihan sehingga pengggunaan suatu metode tidak bisa dikatakan lebih baik dari metode lainnya. Salah satu metode optimasi yang dapat digunakan adalah metode Genetic Algorithm (GA). Metode GA dapat menurunkan rugi-rugi daya secara signifikan dengan cara menentukan penempatan DG yang tepat [2] dan juga untuk menentukan jalur-jalur pair optimal pada jaringan Ad Hoc [3]. Berkaitan dengan hal tersebut, penelitian ini menganalisis bagaimana pengoptimalan titik interkoneksi PLTM untuk menghasilkan rugi daya listrik yang minimal menggunakan metode GA yang merupakan algoritma komputasi yang diinspirasi teori evolusi untuk mencari solusi suatu permasalahan dengan cara yang lebih alamiah. Diharapkan melalui simulasi tersebut dapat diketahui titik interkoneksi yang memeperoleh rugi daya listrik paling minimal pada Penyulang Panji.

\section{KAJIAN PUSTAKA}

A. Sistem Distribusi

Sistem distribusi merupakan bagian dari sistem tenaga listrik. Sistem distribusi ini berguna untuk menyalurkan tenaga listrik dari sumber daya listrik sampai konsumen. Adapun definis distribusi tenaga listrik merupakan sub sistem tenaga listrik yang langsung terhubung dengan pelanggan, karena catu daya pada pusat-pusat beban dilayani langsung melalui jaringan distribusi. Adapun jaringan distribusi dapat dibagi menjadi 2 yaitu sebagai berikut :

1. Distribusi Primer, merupakan jaringan tegangan menengah yang berfungsi untuk menghubungkan gardu induk dengan gardu distribusi. Pada sistem distribusi primer saluran yang digunakan untuk menyalurkan energi listrik ke konsumen disebut penyulang (feeder) [4].

2. Distribusi Sekunder, merupakan jaringan yang berfungsi sebagai penyalur tenaga listrik dari gardu distribusi kepada konsumen tenaga listrik. Besarnya standar tegangan untuk jaringan distribusi sekunder ini adalah 220/380 V, serta 440/550 $\mathrm{V}$ untuk keperluan industri [5].

\section{B. Distributed Generation (DG)}

DG menghasilkan energi listrik dari beberapa sumber energi yang berkapasitas kecil dan dihubungkan langsung pada jaringan distribusi dan umumnya ditempatkan pada bus yang langsung menyuplai pusat beban atau pada gardu distribusi. Berdasarkan fungsinya, DG dibedakan atas dua macam yaitu sebagai unit yang berfungsi untuk mengantisipasi apabila terjadi pemutusan dari suplai daya grid atau standby unit dan juga berfungsi sebagai unit yang dipasang pada jam-jam beban puncak atau peaking unit [6].

Bali sedang mempertimbangkan sumber daya energi terbarukan seperti hidro, panas bumi, matahari, angin, dan biomassa untuk alternatif kebutuhan energi dimasa depan. Sebagian besar biaya investasi awal DG memiliki resiko investasi dibandingkan dengan perencanaan perluasan, karena itu menjadi tantangan untuk mengintegrasikan DG ke dalam jaringan distribusi tenaga listrik. Instalasi DG yang kurang baik dapat menyebabkan kerugian seperti peningkatan rugi-rugi daya [7].

\section{Analisis Aliran Daya}

Analisis aliran daya sangat penting dilakukan untuk menganalisis kelayakan operasi suatu sistem dalam keadaan eksisting bila dibandingkan dengan keadaan sistem untuk masa yang akan datang. Tujuan dari studi aliran daya adalah untuk menentukan tegangan, arus, daya aktif atau daya reaktif pada berbagai macam titik atau bus pada jaringan listrik saat kondisi operasi normal [8].

Dalam load flow analysis pada setiap bus sistem tenaga listrik dapat diklasifikasikan menjadi 3, yaitu [9] :

1. Bus PQ (Load Bus)

Load bus biasanya disebut sebagai Bus $P Q$, karena besaran yang diketahui adalah P (daya aktif) dan Q (daya reaktif).

2. Bus PV (Generator Bus)

Generator bus biasanya disebut bus PV, karena hanya besaran $\mathrm{P}$ dan $\mathrm{V}$ yang diketahui.

3. Bus Ayun (Slack Bus)

Besaran-besaran yang diketahui dalam slack bus adalah $\mathrm{V}$ (tegangan) dan $\delta$ (sudut fasa). Pada umumnya $\delta$ bernilai nol $(\delta=0)$. 


\section{Rugi-rugi Daya}

Rugi-rugi daya merupakan daya yang hilang dalam penyaluran daya listrik dari sumber daya listrik utama ke suatu beban/konsumen yang dapat diakibatkan oleh faktor-faktor tertentu seperti panjang saluran listrik dari sumber ke beban yang cukup jauh, yang juga akan mengakibatkan bertambah besar tahanan (Resistansi) saluran kabel yang digunakan. Rugi-rugi daya tersebut tersebut harus tetap berada dalam batasbatas tertentu. Adapun untuk perhitungan rugi-rugi daya dapat menggunakan persamaan sebagai berikut [10] :

$$
\Delta P=I^{2} \times R
$$

Dimana :

$$
\begin{aligned}
\Delta P & =\text { Rugi daya }(\mathrm{W}) \\
I \quad & =\operatorname{Arus}(\mathrm{A}) \\
R & =\operatorname{Hambatan} \text { Penghantar }(\Omega)
\end{aligned}
$$

\section{E. Genetic Algorithm (GA)}

Algoritma Genetika pertama kali ditemukan oleh John Holland pada tahun 1975 di Universitas Michigan, melalui sebuah penelitian oleh muridnya, David Goldberg [11]. Algoritma Genetika merupakan metode yang menerapkan pemahaman tentang evolusi alamiah pada pemecahan masalahnya. Proses yang digunakan pada Algoritma Genetika dengan cara mengkombinasi secara acak pilihan solusi terbaik pada suatu populasi untuk mendapat generasi terbaik selanjutnya.

Generasi ini akan melakukan perbaikan pada populasi awal. Dengan melakukan generasi secara berulang sampai batas yang telah ditentukan, diharapkan algoritma ini dapat mensimulasikan konsep evolusi dan pada akhirnya permasalahan yang dihadapi akan ditemukan solusi yang tepat.

Dalam perbaikan populasi, perlu ditentukan fungsi fitness yang akan digunakan sebagai acuan untuk mencapai nilai optimal pada Genetika Algoritma, maka fungsi fitness yang digunakan dalam penelitian ini adalah sebagai berikut [12]:

$$
f(x)=\min \left[P_{G E N}+\sum_{\mathrm{i}=1}^{N b} P_{D G i}\right]-\sum_{\mathrm{i}=1}^{N b} P_{L O A D i}
$$

Dimana :

$$
\begin{array}{ll}
f(x) & =\text { fungsi fitness } \\
P_{G E N} & =\text { Generasi dari populasi } \\
P_{D G i} & =P_{G E N} \times N \text { (ukuran populasi) } \\
P_{L O A D i} & =\text { Nilai beban }
\end{array}
$$

$P_{G E N}$ diatas dihitung terhadap hasil perhitungan analisis aliran daya (load flow analysis) dan total dari $P_{D G i}=P_{G E N} \times$ Ukuran Populasi. Nilai fitness function terbaik adalah hasil rugi-rugi daya total paling minimal. Nilai fitness ini yang akan menyatakan baik tidaknya suatu solusi (individu). Sehingga penempatan PLTM ditentukan dari pembangkitan populasi baru secara acak dan diproses dari fitness masing-masing guna mencari individu dengan kriteria fitness paling minimal.

\section{METODOLOGI PENELITIAN}

Penelitian ini bertempat di PT. PLN (Persero) Distribusi Bali Area Bali Utara. Jenis data yang digunakan dalam penelitian ini adalah data kuantitatif berupa single line diagram, panjang saluran, jenis penghantar, jumlah pelanggan, dan data pembebanan pada Penyulang Panji dari PT. PLN (Persero) Distribusi Bali Area Bali Utara. Alur analisa penelitian ini adalah sebagai berikut :

1. Mempersiapkan data-data seperti single line diagram, panjang saluran, data beban, kapasitas daya output PLTM, serta kapasitas daya transformator dari Penyulang Panji.

2. Membuat simulasi optimasi penempatan PLTM pada software dan menginput parameter-parameter yang diperlukan.

3. Analisis rugi-rugi daya dilakukan dalam kondisi eksisting Penyulang Panji saat sudah terkoneksi dengan PLTM. Untuk menganalisis rugi-rugi daya digunakan software dengan tools Load Flow Analysis.

4. Setelah simulasi dilakukan dan diperoleh hasil, selanjutnya dilakukan analisis besarnya nilai rugi-rugi daya pada jaringan distribusi dengan kondisi penyulang setelah PLTM dioptimasi untuk mengetahui penurunan rugi-rugi setelah dioptimasi dengan metode GA. 


\section{HASIL DAN PEMBAHASAN}

A. Gambaran Umum Penyulang Panji

Penyulang Panji merupakan salah satu jaringan distribusi tenaga listrik $20 \mathrm{kV}$ yang disuplai dari Gardu Induk Pemaron, dan juga oleh DG yaitu Pembangkit Listrik Tenaga Minihidro (PLTM) Muara. Penyulang Panji memiliki panjang jaringan mencapai 67,387 $\mathrm{kms}$, dengan total jumlah pelanggan sebanyak 8.110, dan memiliki 51 transformator distribusi yang tersebar di daerah Panji, Buleleng.
Untuk memanfaatkan potensi alam yaitu sumber energi air di Kabupaten Buleleng, Pemerintah membangun satu unit Pembangkit yaitu PLTM Muara yang berada di Desa Sambangan, Bali. Pada PLTM Muara terdapat 2 buah Generator aktif yang masing-masing berkapasitas 1,15 MW. Gambar single line diagram dari Penyulang Panji yang sudah terhubung dengan PLTM Muara dapat dilihat pada Gambar 1 [13].

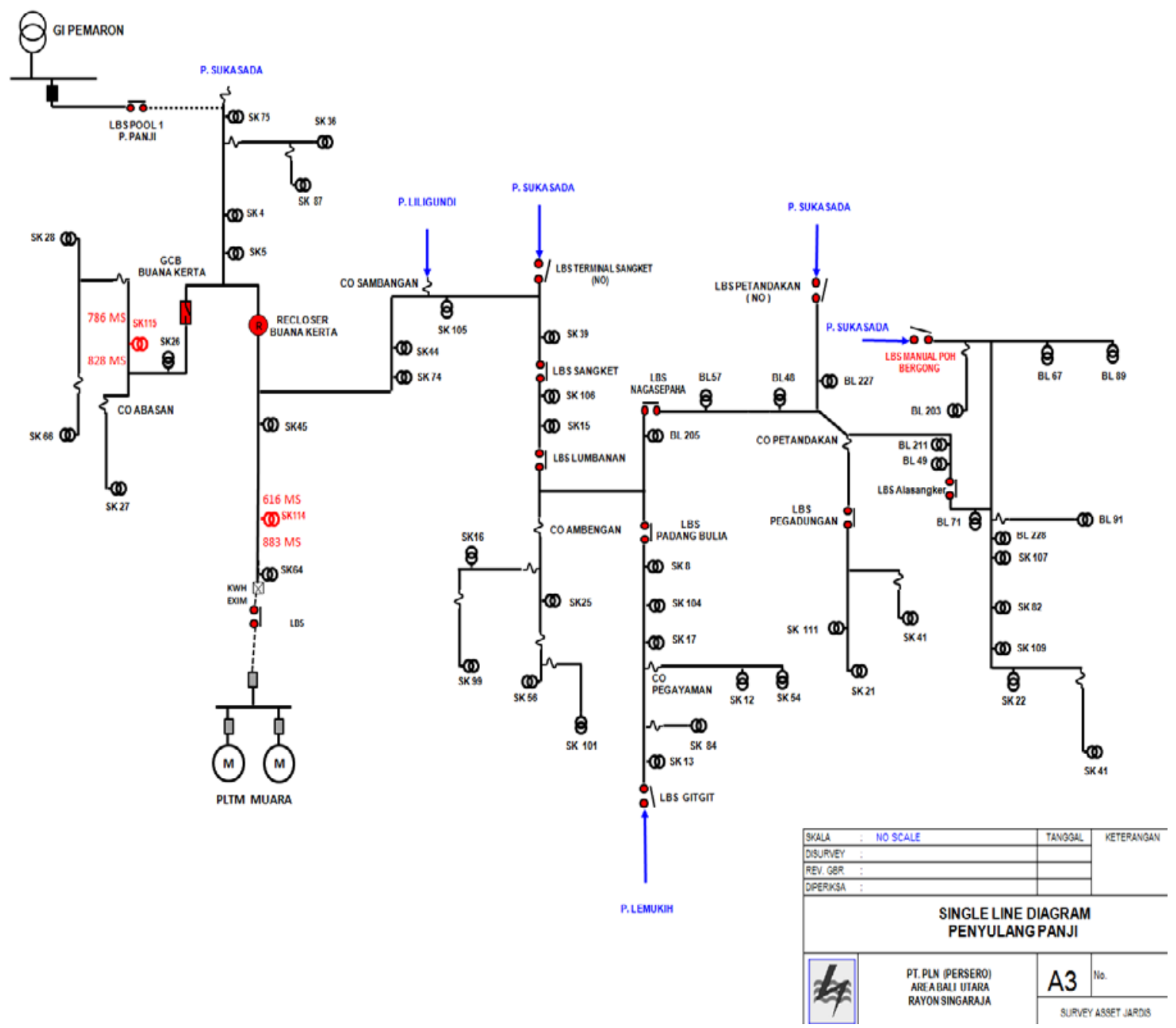

Gambar 1. Single Line Diagram Penyulang Panji 


\section{B. Analisis Rugi Daya Saat} Terhubungnya PLTM Muara

Analisis aliran daya dengan metode Newton Raphson dilakukan untuk mengetahui besarnya rugi-rugi daya yang terdapat pada jaringan distribusi Penyulang Panji sesudah terhubungnya PLTM Muara. Data yang diperlukan dalam perhitungan rugi daya yaitu berupa data beban, pembangkitan, dan data saluran seperti yang ditunjukan pada Tabel 1 dan Tabel 2.

Tabel 1 Data Sumber dan Beban Pada Penyulang Panji

\begin{tabular}{|c|c|c|c|c|c|c|}
\hline \multirow{2}{*}{$\begin{array}{c}\text { Bus } \\
\text { ID }\end{array}$} & \multirow{2}{*}{$\begin{array}{l}\text { Kode } \\
\text { Gardu }\end{array}$} & \multirow{2}{*}{$\begin{array}{c}\text { Tegangan } \\
\text { (KV) }\end{array}$} & \multicolumn{2}{|c|}{ Beban Trafo } & \multicolumn{2}{|c|}{ Pembangkitan } \\
\hline & & & (MW) & (MVAR) & (MW) & (MVAR) \\
\hline Bus1 & $\begin{array}{c}\text { Trafo } \\
\text { GI }\end{array}$ & 20 & - & - & 0,660 & 1,190 \\
\hline Bus 5 & $\begin{array}{c}\text { SK } \\
075\end{array}$ & 0,4 & 0,04 & 0,02 & - & - \\
\hline Bus 9 & $\begin{array}{l}\text { SK } \\
036 \\
\end{array}$ & 0,4 & 0,06 & 0,04 & - & - \\
\hline $\begin{array}{c}\text { Bus } \\
11 \\
\end{array}$ & $\begin{array}{c}\text { SK } \\
087 \\
\end{array}$ & 0,4 & 0,01 & 0,07 & - & - \\
\hline$\ldots$ & $\ldots$ & $\ldots$ & $\ldots$ & $\ldots$ & $\ldots$ & $\ldots$ \\
\hline $\begin{array}{l}\text { Bus } \\
141\end{array}$ & $\begin{array}{l}\text { Trafo } \\
\text { PLTM }\end{array}$ & 20 & - & - & 1,353 & 0 \\
\hline
\end{tabular}

Tabel 2 Data Resistansi dan Reaktansi Saluran Pada Penyulang Panji

\begin{tabular}{|c|c|c|c|}
\hline From Bus & To Bus & $\mathbf{R}(\mathbf{p . u})$ & $\mathbf{X}(\mathbf{p . u})$ \\
\hline Bus 1 & Bus 2 & 0,00082 & 0,00067 \\
\hline Bus 2 & Bus 3 & 0,03161 & 0,0025 \\
\hline Bus 3 & Bus 4 & 0,00328 & 0,00502 \\
\hline Bus 4 & Bus 5 & 1,92439 & 5,94636 \\
\hline$\ldots$ & $\ldots$ & $\ldots$ & $\ldots$ \\
\hline Bus 140 & Bus 141 & 0,00447 & 0,00364 \\
\hline
\end{tabular}

Tabel 1 dan Tabel 2 merupakan data input untuk analisa aliran daya dan perlu dilakukan penentuan MVA Base yang akan digunakan. Pada penelitian ini menggunakan MVA Base 100 MVA. Sehingga setelah dilakukan analisa aliran daya, besar rugi-rugi daya total sesudah terhubungnyanya PLTM Muara saat kondisi eksisting pada bus 35 transformator SK 64 dapat dilihat tabel Tabel 3.

Tabel 3 Data Hasil Analisa Aliran Daya Sesudah Terhubung PLTM

\begin{tabular}{|c|c|c|}
\hline No. & Klasifikasi & Nilai \\
\hline 1. & Total Daya Aktif GI & $660 \mathrm{~kW}$ \\
\hline 2. & Rugi Daya Aktif & $36 \mathrm{Kw}$ \\
\hline 3. & Total Daya PLTM & $1.353 \mathrm{~kW}$ \\
\hline
\end{tabular}

\section{Analisis Interkoneksi PLTM Dengan Metode GA}

Perhitungan rugi daya kondisi eksisting interkoneksi PLTM di bus trafo SK 64 pada Penyulang Panji akan digunakan sebagai data input untuk menentukan lokasi titik interkoneksi PLTM dengan metode GA. Dalam analisa perlu diperhatikan juga jarak antara PLTM dengan titik interkoneksi pada Penyulang Panji karena akan berpengaruh terhadap rugi daya. Interkoneksi PLTM Muara berada di Desa Sambangan yang memiliki jarak $1800 \mathrm{~m}$ dari jaringan Penyulang Panji. GA bertujuan mencari individu dengan nilai fitness yang paling baik. Maka fitness function yang digunakan pada penelitian ini seperti persamaan (2). Hasil analisis dari metode GA dapat dilihat pada Gambar 2.

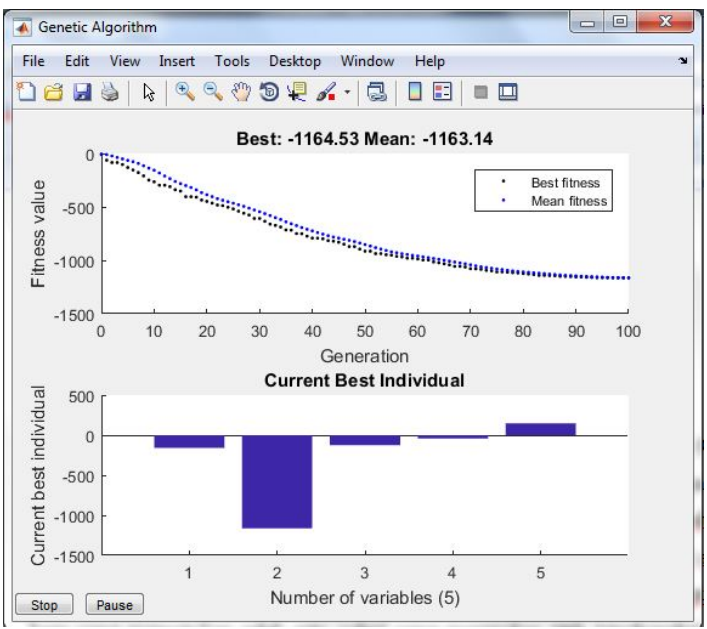

Gambar 2 Grafik Generasi Metode GA

Gambar 2 adalah proses siklus GA yaitu, Populasi awal - Evaluasi fitness - Seleksi Individu - Reproduksi : Crossover dan Mutasi - Populasi baru - Evaluasi fitness. Siklus tersebut akan berulang sampai 100 kali generasi sehingga menghasilkan suatu populasi baru yang menyatakan salah satu solusi dan akan didapatkan setelah nilai fitnessnya stabil seperti ditunjukan pada Gambar 2.

Dalam proses optimasi, akan dibangkitkan sejumlah kromosom (sesuai dengan ukuran populasi) untuk dijadikan anggota populasi awal atau kondisi penyulang awal. Populasi itu sendiri terdiri dari sejumlah kromosom yang akan dihubungkan PLTM untuk memperoleh nilai fitness yang mewakili nilai rugi pada jaringan. Nilai fitness suatu bus menggambarkan nilai rugi-rugi pada bus dalam populasi tersebut.

Setelah inisialisai populasi, kemudian dilakukan evaluasi individu dengan proses seleksi atas hasil nilai fungsi fitness dari setiap 
kromosom, dari proses seleksi inilah dijaring individu terbaik dari sekumpulan populasi yang ada yaitu titik interkoneksi PLTM Muara dengan rugi daya total terkecil, dan nantinya individu dari kromosom terbaiklah yang mampu bertahan.

Kemudian setelah siklus berjalan, maka kembali dilakukan analisa aliran daya guna mengetahui hasil rugi daya pada lokasi bus yang telah dinyatakan sebagai kromosom/bus terbaik oleh metode GA seperti Tabel 4.

Tabel 4 Hasil Analisa Aliran Daya dan Lokasi interkoneksi PLTM Setelah Optimasi

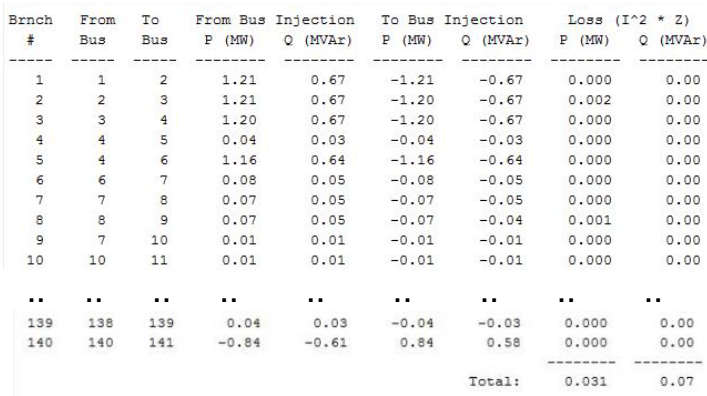

Perhitungan Selesa

Lokasi DG: 70
Rug1-rugi: 0.031037

Tabel 4 merupakan perhitungan analisa aliran daya dari metode GA dan didapatkan titik interkoneksi bus PLTM Muara setelah dilakukan optimasi dengan metode GA terdapat pada bus 70 dengan rugi-rugi daya sebesar $31 \mathrm{~kW}$.

\section{Analisis Rugi-rugi Daya Setelah Optimasi PLTM \\ Setelah dilakukan optimasi, nilai rugi daya} Penyulang Panji menjadi turun. Didapatkan hasil sebelum dilakukan optimasi yaitu pada kondisi eksisting sebesar $36 \mathrm{~kW}$, sedangkan setelah dilakukan optimasi dengan metode GA didapatkan titik interkoneksi PLTM Muara terletak diantara LBS Padang Bulia dan Trafo BL 205 dengan rugi-rugi total sebesar 31 kW yang dapat dirangkum seperti Tabel 5.

Tabel 5 Data Rugi-rugi Daya Sebelum dan Setelah Optimasi PLTM

\begin{tabular}{|c|c|c|}
\hline No. & Keterangan & $\begin{array}{c}\text { Rugi-Rugi Daya } \\
\text { Total }\end{array}$ \\
\hline 1 & Rugi Daya Sebelum Optimasi & $36 \mathrm{~kW}$ \\
\hline 2 & Rugi Daya Setelah Optimasi & $31 \mathrm{~kW}$ \\
\hline \multicolumn{2}{|c|}{ Selisih Rugi-rugi Daya } & $5 \mathrm{~kW}$ \\
\hline
\end{tabular}

\section{SIMPULAN}

Berdasarkan hasil analisis dan pembahasan yang telah dilakukan, maka dapat ditarik beberapa simpulan sebagai berikut :

1. Kondisi eksisting titik interkoneksi DG yaitu PLTM Muara pada Penyulang Panji saat ini terletak pada Bus 35 trafo SK 64 yang memiliki rugi-rugi daya total sebesar $36 \mathrm{~kW}$.

2. Lokasi terbaik titik interkoneksi DG yaitu PLTM Muara pada Penyulang Panji setelah dilakukan optimasi menggunakan metode Genetic Algorithm (GA) terdapat pada Bus 70 dengan rugi-rugi daya total sebesar $31 \mathrm{~kW}$.

3. Interkoneksi DG pada Bus 70 di Penyulang Panji dapat menurunkan rugirugi daya aktif sebesar $5 \mathrm{~kW}$ dari total rugi-rugi daya awal saat kondisi eksisting yaitu pada Bus 35 sebesar 36 kW menjadi $31 \mathrm{~kW}$.

\section{DAFTAR PUSTAKA}

[1] Satriya Utama, N. P., Hartati, R. S., Ariastina, W. G., dan Swamardika, I. B. A. A Placement and Sizing of Distributed generation Based on Combines Sensitivity Factor and Particle Swarm Optimization: A Case Study in Bali's Power Transmission Network. Int. J. Eng. Emerg. Technol., Vol. 2, No. 2, 2017.

[2] Sabilla, N. H., Nugroho, A., dan Handoko, S. Optimasi Penempatan Pembangkit Terdistribusi Pada IEEE 30 Bus System Menggunakan Algoritma Genetika. Transient, Vol.2, No.3, 2013.

[3] Gunantara, N., \& Dharma, A. Optimal Path Pair RoutesThrough MultiCriteriaWeight In Ad Hoc Network Using Genetic Algorithm. International Journal Of Communication Network And Information Security (IJCNIS), Vol. 9, No. 1, 2017.

[4] Affandi, S. Analisis Keandalan Sistem Distribusi Tenaga Listrik di Gardu Induk Indramayu. Yogyakarta : Universitas Muhammadiyah Yogyakarta, 2015.

[5] Suswanto, D. Sistem Distribusi Tenaga Listrik. Padang : Universitas Negeri Padang, 2009. 
[6] Sunanda, W. Perbaikan Keandalan Sistem Melalui Pemasangan Distributed Generation. Jurnal IImiah Foristek Vol.3, No.2, 2013.

[7] Satriya Utama, N. P., Hartati, R. S., Ariastina, W. G., Swamardika, I. B. A., dan Penangsang, O. A Review on Model of Integrating Renewable Distributed Generation into Bali's Power Distribution System: Issues, Challenges, and Possible Solutions. Indones. J. Electr. Eng. Comput. Sci., Vol. 4, No. 2, 2016.

[8] Grainger, J. J., dan Stevenson, W. D. Power System Analysis. New York, McGraw-Hill Book Company, 1994.

[9] Sulasno. Analisis Sistem Tenaga. Semarang: Badan Penerbit Universitas Diponegoro, 1993.

[10]Tanjung. A. Rekonfigurasi Sistem Distribusi 20 kV Gardu Induk Teluk Lembu Dan Pltmg Langgam Power Untuk Mengurangi Rugi Daya Dan Drop Tegangan. J. Sains Teknol. Dan Ind., Vol. 11, No. 2, 2014.

[11]Nugraha, I. Aplikasi Algoritma Genetik Untuk Optimasi Penjadwalan Kegiatan Belajar Mengajar. Makalah IF2251 Strategi Algoritmik, 2008.

[12] Zainuddin, M., Suyono, H., dan Dachlan, H. S. Optimasi Injeksi Photovoltaic Distributed Generation (PVDG) Menggunakan Metode Algoritma Genetika. Jurnal EECCIS Vol. 8, No. 2, 2014.

[13] PT. PLN (Persero) Distribusi Bali, Area Bali Utara. Single Line Diagram Penyulang Panji (soft copy). 2017. 